Article

\title{
From the Antenna to the Display Devices: Transformation of the Colombian Radio Industry
}

\author{
Andrés Barrios-Rubio
}

Citation: Barrios-Rubio, Andrés. 2021. From the Antenna to the Display Devices: Transformation of the Colombian Radio Industry. Journalism and Media 2: 208-224. https://doi.org/10.3390/ journalmedia2020012

\section{Academic Editor:}

Andreu Casero-Ripollés

Received: 30 March 2021

Accepted: 1 May 2021

Published: 11 May 2021

Publisher's Note: MDPI stays neutral with regard to jurisdictional claims in published maps and institutional affiliations.

Copyright: (C) 2021 by the author Licensee MDPI, Basel, Switzerland. This article is an open access article distributed under the terms and conditions of the Creative Commons Attribution (CC BY) license (https:/ / creativecommons.org/licenses/by/ $4.0 /)$.
Faculty of Communication and Arts, Nebrija University, 28240 Madrid, Spain; andresbarriosrubio.abr@gmail.com

\begin{abstract}
Consolidation of the digital environment has become an irreversible global reality and, for the Colombian radio industry, it implies not only assuming a process of transformation in its actions, but, above all, continuous learning. Technological innovation imposes new forms of consumption whose logic corresponds to new systems for the production, distribution and commercialization of information, culture, science and entertainment. Object of study. Adaptation of the radio medium to the digital ecosystem of audiences invites us to focus the attention of researchers on the media's use of web-radio, app-radio and social media; the relevance of sound semiotics compared to other components of the message on users' screens; and the alterations suffered by the business model and productive routines of the radio. Methodology. This research took as its focus of study three Colombian radio stations and their informative stations-Caracol Radio, W Radio, Blu Radio, RCN Radio and La FM - through a mixed methodology. Quantitative instruments-numerical data to monitor activities on social platforms — and qualitative instruments-interpretation of messages and visual composition of the message-allow for the monitoring and analyzing of the performance of the radio medium in the digital environment, and the tactical approach of radio agents to delineate the strategies that promote the expansion, positioning and participation of radio in the Colombian media ecosystem. Results. Normalization of connectivity, ubiquity, timelessness and interactivity are, today, inherent values of the content broadcast by the radio industry, which needs to appropriate the tastes and interests of the audience through multi-device, multi-tasking and multi-user devices. Conclusion. Consumption actions of listeners: users are concentrated on the Smartphone screens, which provides a habit of listening and monitoring that forces the media to incorporate the formatand language - of video into their productive dynamics in order to attract and retain the attention of their audiences.
\end{abstract}

Keywords: radio industry; business model; productive routines; digital ecosystem; digital applications

\section{Introduction}

The history of the media in Colombia, as it happens in other countries, has its origins in the 18th century, with the press. The media broadened its spectrum with radio at the beginning of the 19th century, was projected with television in the middle of the century and globalized with the Internet in the twentieth century. Radio broadcasting arrived in Colombia with the HJN station on 7 August 1929; through the State, a public radio came into convergence with commercial alternatives that emerged from 8 December 1929, with the emergence of the station La Voz de Barranquilla (Barrios-Rubio 2011). Since its arrival, radio has evolved to become, due to its audience, social impact and industrial consolidation, one of the most important mass media communication in the country. It went from being seen as a scientific curiosity to positioning itself as a modern means of mass communication that, around music, news, sports, humor, events and contests, captures the attention of the Colombian public (Barrios-Rubio 2020).

Currently, radio adapts its actions to the demands of society and appropriates the advantages that technology brings to its broadcasting systems (Barrios-Rubio 2011). The 
positioning of screens of technological devices in the consumption processes expands the business model and the productive routines of the radio medium to satisfy the needs of the modern audience: presence on the Smartphone, broadcasts on the air and streaming in webmedia and app-radio ruptures the synchronous communication model with the podcast, the coincidence of the sound semiotics with the audiovisual-written in the structure of the discourse-visualization of the medium in the social settings of the network and the timelessness of consumption, among other factors. The business model has adjusted to listeners who, with a traditional transistor, become users and tune in in various ways (web, Smartphone and other modern devices) (Barrios-Rubio 2020).

The current media map reveals the characterization of a new audience-people immersed in visual and multimedia culture who centralize all their consumer actions in the Smartphone. This is a scenario in which there is a hybridization of local forms with the international agenda; sharing a world that is recognized and rethought from the mediation of the subject with the environment. ICTs have not only shaped the culture in which they live, but also rethink the subject's relationship with the media they use; the audience establishes new interaction strategies with the media industry, which influences what they think and how societies behave.

The radio industry in the Colombian media ecosystem reflects a habit of auditory consumption, consolidated online (29\%) and offline (89\%) (Kantar Ibope Media 2019). This is a phenomenon that denotes majority access from mobile phones (Figure 1); a situation that makes the Smartphone a key piece for the future of the hearing industry (Barrios-Rubio and Gutiérrez-García 2016). The conventional and virtual dynamics of a sector intervene in the personalization of an audiences' sound card (Bull 2010) of the national economy, which does not ignore the great mass of listeners but does focus on specific niches of users.
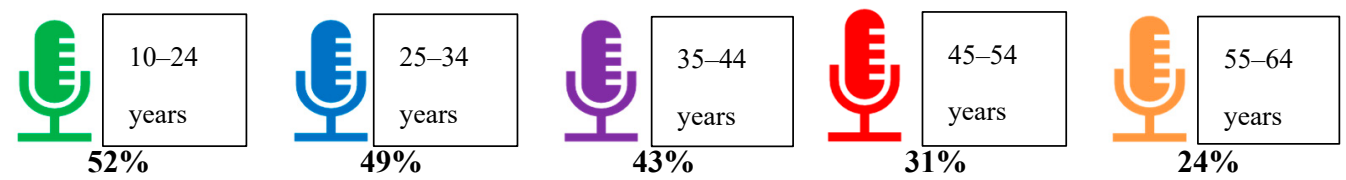

Figure 1. Search by voice or voice commands in a month. Source: own elaboration with Hootsuite 2020 data.

The internalization of the environment in online, digital scenes in which the sound media industry reinvents and diversifies its business model (Barrios-Rubio 2020), productive routines (Said et al. 2013), content distribution systems (Marta-Lazo and Ortiz 2016) and narratives (Martínez-Costa 2015) in the digital sonosphere (Barrios-Rubio 2020) positions the brand of the medium as consumer needs of the audience. The radio-listener-user relationship goes beyond the sound component, as rethinking, adaptation, reconfiguration and reinvention of the sound industry faces the productive dynamics of new media.

Although the phenomenon is global, stopping in markets defined a priori by centers of interest or by geographic area, as is the case in this article, allows us to analyze the dynamics of content production (Said et al. 2013), and thus assess their implications on the consumption of the product by the audience in a given media ecosystem. At a time of convergence and transition, such as the one we are going through, it is important to pay attention to this transformation of the radio industry that faces the dilemma of "continuing to be a sound medium that retains its essence, or to join the technological convergence by moving to be a multimedia, with all that this implies in terms of production" (Crovi et al. 2006, p. 200). However, is that what radio audience expects in a digital ecosystem?

The new dynamics of the market capture the attention of countless digital followers who, under their technical and cultural skills, establish their own agenda of sound consumption as a consequence of the digitization process in the distribution and reception of content produced from the conventional medium and digital platforms. Reception media fragment the audience and the media-mix consumption of the informative, cultural, scientific and entertainment content that circulates daily in the mass media. A pact of 
simulation, autonomy and control, in which a domestic micro-policy of tensions and disputes is developed to maintain the dominance and power of the communicative flow in an environment where the off position is symbolically erased, is important, since no one wants to disconnect.

The purpose of this paper is to determine how the business models and productive routines of the Colombian radio industry reinvent themselves when facing the convergence of media and platforms in order to progress in understanding the changes derived from introducing ICTs into today's society. The following research questions were addressed to focus the lines of action during the project's development:

RQ1. How does the Colombian radio industry use web-radio, app-radio and social networks?

RQ2. Does the sound lose relevance compared to other elements of radio communication with its listeners/users?

RQ3. How is the business model and the productive routines of the Colombian radio station altered in the digital ecosystem?

\section{Theoretical Development}

In the world, radio has shaped part of the world's history by offering a space for citizen participation that allows generating local, regional and national identities within the community in general (Lizondo 2018). This means of communication and subject matter is now facing a huge milestone in its evolution process, namely the digital impact on the media ecosystem and audiences (Tietaah et al. 2019). The radio industry adapts to the market dynamics, new devices and communication models (Barrios-Rubio and Miguel 2021), as the use of radio is being reinvented once again through the Internet. Typical radio schemes continue to exist, but new parameters from the digital field are added. Although the business core is still on the air (Gutiérrez-García and Barrios-Rubio 2021), radio networks have started to develop a series of strategies that allow online growth in an attempt to make stronger and more visible brands that conquer new markets. They are changing from a vertical communicative process to providing audiences with an important role. (Martínez-Costa and Hortelano 2020).

\subsection{Radio and Its Transformation}

Similarly, as in other times of its history, the radio industry reinvents itself and adapts to particular situations in a social context, as well as to technological challenges. After two-and-a-half decades of digital impact on the media ecosystem, radio is facing a profound process of reengineering of its business model (Larrondo et al. 2020) and productive routines. This cultural and entrepreneurial change generates an analog-digital convergence from the radio (McMullan 2020); such a matrix model becomes a pairing of an on-air experience and digital innovation that establishes strategies to build loyalty and attract the attention of new audiences (Cardona Bedoya and González 2019).

There is a fusion of conventional and digital means (Rajendran and Thesinghraja 2014) aiming at cross-media broadcasting and a trans-radio product (Martínez-Costa 2015). Listeners have mutated from the transistor to portable devices (laptops, tablets, mobile phones and other audio terminals with Internet connection) (Pedrero-Esteban et al. 2019), where they can find not only stations transmitting in Hertzian waves but also independent and alternative proposals breaking through this global broadcast system. Web-radios, app radios, social networks, podcasts and streaming are quickly positioning themselves at the core of the media ecosystem, in the center of the communication environment. These productive instances reconfigure the radio in four fields, namely, industry, product, technology and reception.

Radio as an industry is reshaping its role to confront the characteristics of a new audience that, today, focuses on portable device screens. There has been an impact on how radio broadcasting is understood and how narrative is developed. In a process of 
integration, innovation and transformation in the organizational and technological areas (Soengas and Sobrino 2018), radio stations seek to consolidate, design and make their media brands visible (Gutiérrez-García and Barrios-Rubio 2019), regardless of the platform used to communicate content to the user-listener. It is an action strategy intended to consolidate audience niches already attached to a specific technology.

The media ecosystem requires the radio industry to configure its performance under programing, audience and advertising standards (Martínez-Costa et al. 2019) impacted by the technological environment; a social adaptation that reshapes and reverts professional habits built during many decades and displayed through the monopoly of words. They face a more open, interactive context where radio as a means and its radio agents must understand and learn how to perform in such a context.

\subsection{The Radio and Its Sound Product}

Radio products face the revitalization of genres and formats that had been left aside due to the immediacy of podcasts and social scenarios, which respond to the need for content for an audience immersed in the digital landscape (Pérez Tornero and Esteban 2020); such audience approaches the sound product through other means and at times other than live broadcasting (customizing consumption to the particular needs of the listener regardless of time and place). Such a phenomenon of multimedia convergence entails a communicative symbiosis of the sound product complemented by textual, graphic and visual formats.

The appropriation and adaptation of languages and formats leads to simultaneous productive routines on the air and internet (Barrios-Rubio and Miguel 2021). Time setting and radio narration seek to inform, entertain and accompany listeners (McHugh 2016). Radio assumes challenges of a media ecosystem impacted by the digital environment of audiences, as well as thinking and performance under productive routines based on the multidirectional nature of today's communication (Nogueira and Miguel 2019). Contents suitable for the communicative scheme of the digital world seek to transcend the future among the audience, and continue to exist throughout time (Appel et al. 2020).

\subsection{Radio in the Audience's Digital Ecosystem}

The network and digital environment as a technological phenomenon require radio to make use of its ability of closeness and dialog with listeners to extend the conversational setting and build a strategy of digital presence based on leadership and enticing features of values, culture and behaviors surrounding the media's brand. The radio industry and its users are undergoing ICT acculturation and internalization; they are balancing their sensations and becoming aware of such sensations to incorporate them into their daily lives. This use and appropriation of work acts as a symbol to interact with the other party (Orihuela 2015).

Such a space of innovation and immediacy generates new ways to interact with the audience, provides an additional channel for broadcasting contents and establishes conversational space among users. Informative processes are decentralized, the radiolistener-user relation changes (Smahel et al. 2020) and implicit and explicit decision-making processes on broadcast, reception, channel and message authorship are discussed. In other words, the audience is part of the production chain of the radio industry (García Jiménez et al. 2018). The network becomes a center of information and an infinite source of reflections that change and provide feedback at the same speed as new technologies; a process that used to be managed and governed by radio broadcasting.

The new scenario poses a challenge to reception; the radio industry must generate and experiment with strategies to create an impact on the audience. This biosphere not only integrates production, broadcasting and reception of content, but it also connects how they relate in a mediatic, interactive and dialogic manner (Flaxman et al. 2016). The radio industry forms and groups a user community (Monclús et al. 2015) that shares common 
interests in the physical and digital world, and it allows radio to become a reference and source of information for the network.

Users query information in diverse means simultaneously in order to determine the context, meaning and impact of news. Radio in a digital environment must meet an audience's information needs, but also the expectation of user recognition. The anthropological approach discusses inductive logics where the aca-fan seeks $15 \mathrm{~min}$ of fame. Franquet et al. (2013) describe this as a community craving to be heard and for their questions to be incorporated into content production.

Web media are going to become the foundation of the communicative ecosystem; they have won a large portion in terms of audience but are still falling short from a logistic and economic point of view. For this reason, radio intends to adapt to the digital environment of audiences so it can continue to be a benchmark within the media industry. This digital strategy is based on four factors: the need to generate traffic, support for the work performed on the air, being part of network trends and participation in the user conversation (Cabrera 2016).

There is a digital acculturation process where the ICT are used and appropriated to redefine oneself under a series of features that determine how to relate to others and the environment. Working with today's audience implies responding to the logic of an @ user generation (Gutiérrez-García and Barrios-Rubio 2021), and learning how to state and tell stories in a different way, since everything goes through the web and social networks are everybody's meeting point (Orihuela 2015).

The audience in the network becomes a thematic user that searches precise facts, and news captures the audience since they are alert for world events. Business dynamics (Barrios-Rubio and Gutiérrez-García 2017) change and the radio industry must incorporate information material into the digital ecosystem; this material can be employed by users to increase their experience in topics of interest. Radio transforms into a content manager, creates and implements strategies for the digital environment and grows through the eyes and ears of the brand in the network, as stable and lasting work relations are established with the followers (Pérez Tornero and Esteban 2020).

Radio is undergoing a philosophical revolution; it must be reviewed as an information system and a means of communication to create new structures, formats and audiences. There is a digital environment where $80 \%$ is strategy and $20 \%$ is technology; the tactic means for the network what personality means for an individual. If content is the king, interaction is the queen and analysis is the empire (Boyd and Ellison 2008). Consumers' mindsets have changed; users respond to multiple screens, languages and schemes, where touch, image and interaction are priorities, while sound is an indispensable complement.

\subsection{Colombian Sound Ecosystem}

The Colombian radio industry is formed by 1589 radio stations ( 660 commercial, 305 of public interest, and 624 community stations) that use the radio-electric spectrum. Their percentage of market penetration has varied (Figure 2), and has decreased since 2016, which entails the urgent creation of an organizational model focused on modernizing the radio production chain by substituting the on-air-centered vertical system. The peak of growth in 2013 and 2014 was associated with the entry into competition of a new radio network, BLU Radio. Radial innovation had not happened since the 80s, and that generated expectation among listeners, a phenomenon that redefined the audience levels between broadcasters and reacted to the radio industry. After the expectation, the sound market lost attention, and penetration rates fell to the levels of previous years. 


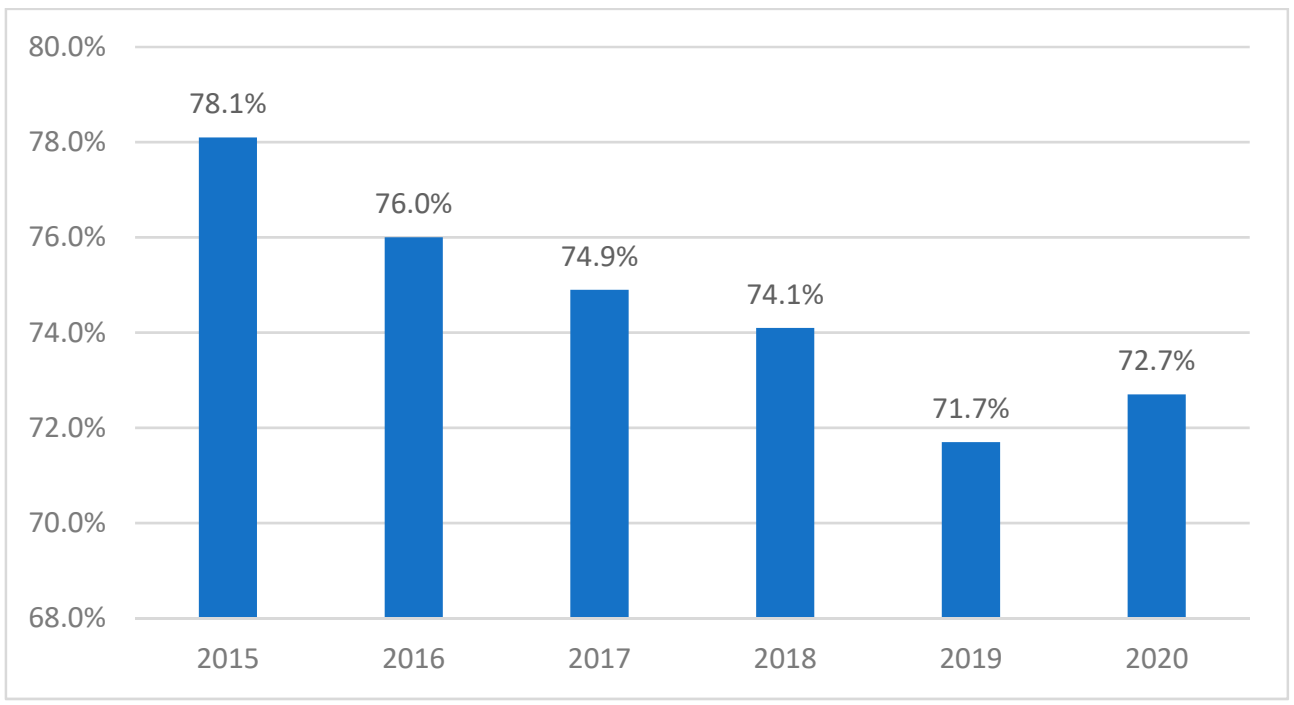

Figure 2. The radio station and its penetration in the Colombian media market. Source: author's elaboration with data from Asociación Colombiana de Investigación de Medios 2020.

Radio faces a new media landscape, where television loses ground in penetration rates $(86 \%)$; the internet, with new media and social communication platforms, is already in the consumer preference, with a standard $93 \%$. These numbers encourage radio to undergo a period of transition and re-planning in its business models, productive routines, contents and broadcasting channels, dividing actions into on air and digital ecosystem (see Figure 3). In total, $85 \%$ of Colombians consume radio medium sound products, a high percentage from the traditional transistor, but many from their screen devices, as the Smartphone is at the epicenter of access to the audiovisual content of traditional media portals (Asociación Colombiana de Investigación de Medios 2020).

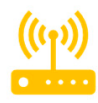

Total Radio Consumption $85.1 \%$

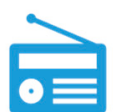

Traditional Radio Consumption $83.4 \%$

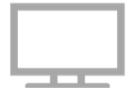

Radio Consumption Digital Content $59.6 \%$

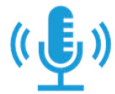

Podcast consumption $29.3 \%$

Figure 3. Consumption of sound content in Colombia. Source: author's elaboration with data from Asociación Colombiana de Investigación de Medios 2020.

The scenario (Figure 3) shows new dynamics for audiences to interact with and face communication means. The radio industry on the air focuses its program offer based on the generalist ( $28 \%$ of the global signal) and thematic $(72 \%)$ models (Asociación Colombiana de Investigación de Medios 2020), following the daily and weekly modus operandi of listeners. Radio stations aim at a homogenous radio formula that mixes seven radio genres in its development (Barrios-Rubio 2020)—informative, info-entertainment, entertainment, sports, music, youth and info-humor-that connect to the six typical formats (Barrios-Rubio 2020) of the means-shows, news, sports, music, debate and talk. These production routines are now interacting with a media panorama to compete with traditional media, web media and communication platforms.

Simultaneously, as technology advances and variations occur in the constant construction of social tissue, radio explores new ways of communicating, creating niches, opening room for citizen participation and establishing consumption strategies that foster the expansion and positioning of the industry in the Colombian and international markets. This radical change not only covers the actions and habits of media agents but also those of the audience (Aguaded and Romero-Rodríguez 2015). It is a corporate, technological, professional and communicative convergence where the radio industry explores a narrative 
system that responds to multiple tools of emission, transmission and reception that are the center of today's market.

Listeners, who have now become users, look for new concepts and communicative proposals in the mass media, including sound and non-sound contents that respond to the dynamics of a hyper-connected audience. The web-media (Barrios-Rubio and GutiérrezGarcía 2017), or radio 3.0 (Sádaba Chalezquer and Pérez-Escoda 2020), as well as functional reengineering content and media reengineering are now stronger for meeting an audience's needs successfully, and, thus, the radio industry extends its leadership and information reference.

The emergence of digital culture and an interrelation with the environment, channeled in an increasingly generalized way through social networks, forces the radio medium to be present on all platforms and achieve a return on the investment made in each iteration. An atmosphere in which profitability is no longer calculated in only economic terms but also in social terms-volume and impact on followers-is an effect derived from the reception habits towards which journalistic diversification strategies are oriented: integrated newsrooms that, with general competences, attend to specific topics to capture audience niches; formats that combine languages and media in order to expand a story; or immersive content design that offers control to the user for a more personal experience.

The internalization of the environment online by radio and the adoption of new logic to produce informative, cultural, scientific and entertainment content with which to position itself on the digital scene also translates into renewed distribution strategies that include social network-Facebook, Twitter, Instagram, YouTube, TikTok-(Fernández 2018; Pires et al. 2019), channels where radio reinvents listening on the move and facilitates accessibility to the user. The fork between offline and online forces us to conceive messages for interactive screens, with the inclusion of links between texts, graphics, video sequences and animations interconnected and hierarchized among themselves (Pedrero-Esteban and Herrera-Damas 2017). In this way, the redundancy of the message is achieved by leading the user to its consumption not only from their own intentions, but also from the impulse of a digital community which is trying to become akin to the medium.

Efforts of the radio to deploy tactics that allow it to maintain its informational status through streaming or podcast has served to illuminate structures and formats that had been marginalized on the antenna by the productive dynamics of the conventional medium (Gutiérrez-García and Barrios-Rubio 2019): convergent communicative proposals arise that obey the spatial-temporal coordinates of the interactive processes formulated by Jenkins (2008), who suggests that a content that flows through multiple platforms, and which encourages cooperation between different media industries and gives rise to a migratory behavior of audiences, is willing to go almost anywhere in search of the desire for new experiences of entertainment.

\section{Materials and Methods}

Radio in Colombia reaches $91 \%$ of the nation's population, and commercial radio stations have the largest impact on the market, since they attract $96 \%$ of the audience; in contrast to $3 \%$ for public radio stations and 1\% for community radio (Asociación Colombiana de Investigación de Medios 2020). This scenario focuses on commercial radio and general content stations where most of the investment in inputs, financial and human resources is concentrated and the ideological baselines of the radio network are set (BarriosRubio 2016). For the selection of the sample, the following were used: a general study of the media that indicates that the highest tuning rates are concentrated in the 5 generalist channels of national transmission-Caracol Radio, W Radio, Blu Radio, RCN Radio and La FM; number of followers of the stations on the social networks of Facebook, Twitter, Instagram and Youtube (Table 1); relevant growth in digital media consumption in the 2020 quarantine - Caracol Radio and W Radio (+29.24\%), RCN Radio and La FM (+13.20\%) and Blu Radio (-7.49\%); increase in consultations of web domains of the talk radio- 
lafm.com.co $(+7.53 \%)$, caracol.com.co $(+20 \%)$, bluradio.com $(+16.44 \%)$, wradio.com.co $(+62.2 \%)$ and renradio.com $(-9.68 \%)$.

Table 1. Radio and its social followers.

\begin{tabular}{cccccc}
\hline & Caracol Radio & W Radio & Blu Radio & RCN Radio & La FM \\
\hline Antenna & $1,558,000$ & $1,115,000$ & $1,163,000$ & 592,000 & 722,000 \\
Facebook & 965,438 & 937,466 & $2,121,861$ & 731,587 & $1,305,304$ \\
Twitter & $3,718,069$ & $4,012,512$ & $2,696,514$ & $3,036,903$ & $2,397,054$ \\
Instagram & 502,673 & 401,850 & $1,015,481$ & 227,659 & 234,231 \\
YouTube & 92,538 & 184,602 & 251,141 & 122,397 & 53,841 \\
\hline
\end{tabular}

Source. Data from Asociación Colombiana de Investigación de Medios, 2020 and media profiles on social media as of May 31.

After sampling was gathered, the study was structured based on a mixed methodology that addressed the actions of the radio industry on the air and in the digital field as interrelated ecosystems (Tsujimoto et al. 2018). The collection of the corpus for analysis (all messages published on social profiles from 1-31 May 2020 were taken as a basis)-following social networks (the messages of the Twitter accounts of the stations under study were obtained through the Twitonomy platform, and the posts of the Facebook, Instagram and YouTube profiles were taken directly from the social networks), images of web-radio (the web-radio images are taken directly from the web addresses of each station under the composite week criterion-1, 7, 13, 19, 25 May) and app radio (the photographs of the app of each station were downloaded from the mobile application of each radio station under the criterion of compound week-1, 7, 13, 19, 25 May)—allowed for the establishment of the quantitative data of radio station performance schemes and the generalized behavior of the audience (Velásquez et al. 2018); these data were compared to the qualitative analysis (Mayoral and Edo 2014) of messages, as well as digital proposal and creation as tools for the media to reach the audience in different ways.

Data were processed in analysis datasheets previously validated by training assistants, who coded the material so that matches and differences could be established to adjust the variables that lead to confusion (Wimmer and Dominick 1996). The instrument was validated under the Alpha Cronbach coefficient, whose confidence values are $95 \%$ with a margin of error of 5\% (Hernández-Sampieri et al. 2010), thus avoiding any kind of bias (Ortega and Galhardi 2013). The categories of analysis (Table 2) were developed for a comprehensive approach to the subject matter (Barrios-Rubio and Gutiérrez-García 2016). Attitudes and behaviors were observed (Silverman 2000) in the narrative of the media and its users, which allowed us to perform a value assessment at the time of discussion (Urchaga 2009).

Table 2. Categories from which the research analysis is triangulated.

\begin{tabular}{|c|c|c|c|c|}
\hline Platform & Collected Corpus & Category & Definition & Theoretical Criterion \\
\hline \multirow[t]{2}{*}{ Twitter/Facebook } & \multirow[t]{2}{*}{$\begin{array}{c}31.849 \text { tweets } / 13.954 \\
\text { posts }\end{array}$} & Broadcaster's activity & $\begin{array}{l}\text { Communicative actions } \\
\text { of radio to reach users. }\end{array}$ & $\begin{array}{l}\text { Strategy of impact on } \\
\text { the market } \\
\text { (Barrios-Rubio 2015). } \\
\text { Communicative model } \\
\text { of radio with its } \\
\text { audience (Sádaba } \\
\text { Chalezquer and } \\
\text { Pérez-Escoda 2020). }\end{array}$ \\
\hline & & Receiver's activity & $\begin{array}{l}\text { Actions of response, } \\
\text { recognition and } \\
\text { interaction given to } \\
\text { broadcaster's } \\
\text { messages. }\end{array}$ & $\begin{array}{c}\text { Audience's role in the } \\
\text { digital ecosystem } \\
\text { (Serrano-Puche 2017). } \\
\text { Interaction processes } \\
\text { (Soengas and Sobrino } \\
\text { 2018). }\end{array}$ \\
\hline
\end{tabular}


Table 2. Cont.

\begin{tabular}{|c|c|c|c|c|}
\hline Platform & Collected Corpus & Category & Definition & Theoretical Criterion \\
\hline Instagram/YouTube & 657 images/502 videos & $\begin{array}{l}\text { Communicative and } \\
\text { graphic proposal }\end{array}$ & $\begin{array}{l}\text { Visual composition, } \\
\text { content distribution, } \\
\text { iconographic tools in } \\
\text { the interaction with } \\
\text { users. }\end{array}$ & $\begin{array}{c}\text { Reinventing the means } \\
\text { (Barrios-Rubio and } \\
\text { Gutiérrez-García 2016). } \\
\text { Communicative needs } \\
\text { of the means } \\
\text { (Asnira-Zolkeplia and } \\
\text { Kamarulzamanb 2015). }\end{array}$ \\
\hline $\begin{array}{l}\text { Web-radio/App- } \\
\text { radio }\end{array}$ & $\begin{array}{c}25 \text { portal images } / 25 \text { app } \\
\text { photos }\end{array}$ & Content management & $\begin{array}{l}\text { Thematic proposal, } \\
\text { exclusive alternatives, } \\
\text { convergence of video } \\
\text { elements, photo } \\
\text { galleries and } \\
\text { multimedia tools. }\end{array}$ & $\begin{array}{l}\text { Content strategy } \\
\text { (Martí et al. 2019). } \\
\text { Sequences of } \\
\text { productive action } \\
\text { (Scolari and Establés } \\
\text { 2020). }\end{array}$ \\
\hline
\end{tabular}

Source. Made by the author.

The methodological design addressed the entire actions established by the main offline operators of the Colombian radio industry from Monday to Friday in their digital broadcast platforms. A comparative analysis of the content supply detected whether there were any factors that influenced the actions made by broadcasters in their offline area of influence to place the user-listener at the key spot of their road map in the online environment.

\section{Research Limitations}

The environment from which the study is carried out is framed by the particularities that implied the confinement and reactivation of the routines of consumption of traditional media by the audience during the COVID-19 pandemic. The approach to the web-media, app-media and social media of the stations under study outlines a behavior of the radio industry and its audience under the concept of a compound week. Investigative input was ordered and systematized in Excel tables, with the purpose of carrying out an analysis of the information, as well as an integration, connection and evaluation of relationships between the categories and research variables that led to a correlation between the information and the statistical percentages in the SPSS Version 21 program represented in tables.

Analysis sheets, filled out by research assistants, had previous tests that allowed us to guarantee correct application by the coders and thus minimize biases. The correlation of these indicators has made it possible to answer the questions formulated in the research, which constitutes a first approach to the object of study with the aim of expanding it in future works. The study presented here seeks to provide descriptive data of phenomena that occur in a natural environment to make interventions with an experiment or artificial treatment (Taylor et al. 2015).

\section{Results and Discussion}

Analyzing today's radio broadcast phenomenon leads us to recognizing a media ecosystem determined by the bifurcation of scenarios (on air-cyberspace), where one can observe how traditional radio stations migrate to a convergence of media and platforms. In this scenario and based on the specific nature of each radio station, the radio industry redefines its business model and productive routines in the construction of a new media panorama.

The radio stations under study have been strategically grouped based on three corporate groups that own the main communication media in Colombia ${ }^{1}$ in order to present and discuss the results. Each radio network develops a homogeneous scenario based on their administrative policies, where their pool of stations responds to the social and cultural environment of the audience and the new means of media consumption. 


\subsection{Caracol and W Radio Audience-Leading Radio Brand That Captures Attention on Social Screens}

The analysis of results shows that Cadena Radial Colombiana (Colombian Radio Network) appropriated a process of digital acculturation in which the antenna broadcast was adapted to the particular dynamics of web-radio, app-radio and social networks. The websites of radio stations exploit the brand image of the communication means in the audience's imaginary, as well as their association with current events in order to focus the traffic and flow of actions that lead users to specific actions of information consumption. This is why Caracol is in place 13,417 in the Alexa ranking worldwide and place 177 in Colombia; on the other hand, W. Radio is in place 21,543 worldwide and place 256 in Colombia.

The digital design of web pages shows, at a first glance in the header, convergence with the on-air signal (access to streaming of the live show and an image of the program anchor). A menu offers access to specific elements of programs and their audio files, the addition to local content with sound (W includes 4 international cities-Panama, Madrid, Miami and New York, where they have broadcasting stations), podcasts, special contents, blogs, selected information and breaking news. These communication means strategically require user registration so that they can customize content, look for specific topics and interact with the information trends of the day (\#) that the station transfers to social networks.

The body presents a thematic distribution of the page divided into boxes $(20$, on average), in line with the navigation chart displayed in the upper section of the user. The contents ( 77 pieces- $66 \%$ information releases, $12 \%$ podcast, $17 \%$ videos and $5 \%$ photo galleries) are supported by strong visual aids, very short and suggestive texts so that users may click on them immediately, and they can support the informative development of the text with multimedia material, a typical characteristic of trans-radio narratives. Images and sound pieces of the show's guests and analysis segments become relevant at this point. In other words, the digital ecosystem synthesizes the elements that were developed in an on-air environment.

Radio privileges sound over other multimedia components, and it incorporates material that is exclusive for the web. It is a space where a character makes a statement and presents a posture on a particular topic. However, it is highlighted that Caracol and W integrate audiovisual competences into their production routines in the digital ecosystem. Such audiovisual competences are evident in the extensive photographic galleries and multiple videos that are incorporated into the network and shared in Facebook Live, plus the videos that circulate through social media or are the result of alliances with television media. There is a hyperlink in the footer, which connects not only to the social media of the radio station but also to the different media of Prisa group.

The exploration of each one of the digital platforms used by radio stations shows a convergent distribution of contents whose purpose is to provide a response to a new type of consumption that has adapted to the devices and mobility of users. The range of sound and multimedia alternatives distributed in the web-radio ( $79 \%$ of their own material, $4 \%$ press agencies, $5 \%$ other media, $12 \%$ social networks) is transferred to the app-radio and designed as mechanisms of promotion, engagement and expansion in social media-a scenario of participation and involvement where audiences access contents with iconography ( $60 \%$ text, $16 \%$ sound, $19 \%$ audiovisual and $5 \%$ photography), both national and local, from the screens of their mobile devices while creating music lists, accessing other information and scheduling an alarm clock with the radio station.

On social media, Caracol and W display a convergence of the stream of listeners on the air, with the action of Twitter and Facebook platforms. The study period analyzed 7.023 tweets, 3.024 posts, 39 images and 146 videos of Caracol; and 8.038 tweets, 3.171 posts, 198 images and 160 videos of $\mathrm{W}$. They outlined the intention to become a point of reference in the news for the network with the news and topics that are on the air $(79 \%$ of publications). A corporate strategy in the use of the social media was proven and, as a result, RT or sharing publications from other accounts (8\%) became activities with less 
relevance. The verticality and linearity of the media user communicative scheme are kept, given the fact that there are few messages that ask the audience questions (12\%). Moreover, promoting podcasts is an action with almost no relevance (1\%).

Exploring the results provides an explanation of a strategy which promotes radio stations on social media. The message is linked to the tendencies of the communication platform (59\% of publications), and users are encouraged to follow-up on the development of the information by using a hyperlink that leads to the web-radio (95\%). The messages on social media (Graph 3) are specifically correlated to the content to be expanded: audio $(4 \%)$, video from other media $(0 \%)$, text and photography $(79 \%)$ and own multimedia content $(17 \%)$. This audiovisual production routine generates important playback from the audience $(82 \%)$ and reveals a new communicative scheme with radio for its followers.

This is a business model and production routine strategically supported by users. By means of its specific actions on social networks, radio intends for followers of particular networks to contribute to the dissemination, expansion and positioning of the content strategy being implemented. The actions of response, recognition and interaction from the audience allows the determination of a degree of performance on the page such as this: $9 \%$ on Twitter, $36 \%$ on Facebook, $4 \%$ on Instagram and $89 \%$ on YouTube of Caracol; and $16 \%$ $25 \%, 16 \%$ and $84 \%$ of $\mathrm{W}$, respectively. These figures, once interpreted by the radio industry, explain the success, failure or level of counterproposal that must be adopted to continue to be a reference in the consumption of information and entertainment contents, regardless of the communicative ecosystem where it unfolds.

\subsection{Blu Radio, a Young Station on the Dial and with a Digital Vein}

This radio station is characterized on the air and its digital actions are deemed as a fresh proposal, a business scheme whose model and production routines include elements that draw the attention of the audience known as millennials ${ }^{2}$. Its corporate actions implicitly embed the appropriation of the resources provided by ICT. Just like other media, Blu Radio displays the connection and interaction between air-cyberspace by associating the image of the radio station to live audio in the dial, the image of the radio agent and the program being broadcasted. Blu differs from its competitors in the sense that it links an offer of exclusive content to the digital ecosystem: a live music channel and a podcast.

The circulation of users reported by this website places it in position 12.837 of the Alexa world ranking and in position 146 in Columbia. Its ranking is consistent with the importance of the medium in the country and its global impact. Its digital map is articulated by a menu that retains the traditional theme classification of the news, but it highlights the main sources of the daily information agenda. The website header promotes the interrelation of the informative component, digital production, the hyperlink to the social networks of Blu and the access to the sound of Blu radio stations in the country and the regional news.

Blu's proposal is to show that sound is its distinctive competition in the industry. This is the reason why almost all the products of its web page (41 pieces- $82 \%$ information notes, $18 \%$ podcast) are accompanied by the development of that news story on the air. The narrative development of the web portal consists of a series of eight boxes or subdivisions that use the traditional scheme of the press: header, picture and lead to give continuity to the proposal in the top menu. As far as the ichnographic content is concerned, each note is accompanied by an element that specifies whether the material has text (63\%), audio (23\%), video $(13 \%)$, pictures $(1 \%)$, or a combination of them.

Along the same line of the production scheme of the media in the digital component, Blu allocates space in its web page to promote the podcast series of the station. It is a tactical triangulation that associates the new productive fashion to the title of some series, and the image and name of the director. Like its competitors, this radio station allows access to the audio of the programs (it is classified minute by minute or by full transmission). Sound production is articulated with the multimedia components that highlight the viral stories on social media and how the radio station connects with them. 
The image-brand of the radio station, its accounts on the different social networks and other media portals of the group Blue is a part of, is strengthened in the footer, and the user is invited to download the app-radio to have the radio station on portable devices. App-radio is a digital application that synthesizes the web contents of the radio station (93\% own material, 7\% social networks), but, at the same time, users are able to personalize the radio station on their mobile phones. It also establishes the navigation route and notifications that the user wishes to have at a given time.

A multiplatform strategy of brand positioning and, at the same time, a convergence strategy of dissemination of content, was found when comparing research data. This radio station is the most active one on social media (12.099 messages-8.615 on Twitter, 3.275 on Facebook, 126 on Instagram and 83 on YouTube-). The presence of the radio station on communication platforms is consistent with the number of listeners on the air, which promotes an air-cyberspace synergy that vitalizes its positioning in the media market. Blu's digital strategy is consistent with its purpose of reaching out to the millennial generation.

The radio agent, like its competitors, allows the establishment of a significant concentration of informative messages and topics that are addressed on the air (85\%), as well as facts that give it recognition as a reference of actuality and immediacy on the network. The Blu commitment is to strengthen its sports section and take advantage of its journalists' prestige and image, so there is a growing flow of publications $(6 \%)$ sharing what has been written on those profiles. It is remarkable that, in the digital strategy, the challenge undertaken by Blu to generate exclusive products for the web had not been expanded to social networks shows that little effort was made to promote podcasts $(2 \%)$ and to query followers' opinion (7\%).

The qualitative analysis of the sample reiterates the multichannel integration through hyperlinks to the radio station's website (93\%), programs profiles (1\%) and other media of the group $(6 \%)$. The structure of the iconographic message suggests to the user the kind of complementary elements that accompany the content: audio (17\%), video of other media (5\%), text and photography $(56 \%)$, and its own multimedia content $(22 \%)$. It is Blu's audience that produces most reproductions (97\%) of audiovisual production that it provides on Facebook Live, a key space to revitalize the production model of the radio on multiple screens provided by the audience.

The fact that Blu has greater presence and activity on social networks manages to generate links of commitment between users and the radio station (25\% on Twitter, $61 \%$ on Facebook, $10 \%$ on Instagram and $87 \%$ on YouTube). Additionally, Blu's followers have adapted their sound consumption to the dynamics proposed by this radio station on the web-radio and app-radio. It is a scenario where podcasts are positioned, since Blu used referents of the radio industry to promote a differential product with its competence in the Colombian media market.

\subsection{RCN and La FM, Crisis in Audience on the Dial That Moves to the Social Scene}

Radio Cadena Nacional has faced an identification crisis with its audience for two decades. This phenomenon is shown in EGM tuning results. The transcendence, benchmark and recognition of RCN, however, do not seem to be affected in the digital landscape. Alexa ranking provides global recognition to $\mathrm{RCN}$, which is classified in 22.334th place and 298th in Colombia. FM is classified in 18.026th place of the world and locally in 247th place.

The websites of the radio stations address the public dynamics of their respective audiences. The format of RCN is adult contemporary, and the audience of FM is the millennial generation. The direct competitors of RCN are Caracol and W, while Blu radio is a direct competitor of FM. RCN, as its peers do, establishes dynamics in its header in line with the station (streaming by cities, name of the radio show, picture of the anchor), the information thematic subdivision and the links to the radio station's social networks. The differentiating factor is the possibility of accessing audio files, videos, photo galleries and a webcam as main breaking news is being broadcasted. 
The radio group privileges the digital strategy of in-cab video, radio that is watched and an image that is also shared on social networks. The narrative development (16 average boxes) has some common elements: headline, photograph and lead, with audio iconography, video or photography, which these radio stations complement by highlighting the most browsed events on the website throughout the day. The information hub (49 pieces- $84 \%$ information notes, $5 \%$ podcast, $10 \%$ videos and $1 \%$ photo galleries) that matches with the classification provided in the menu is complemented by a survey of the day, the self-promotion of the programs and an invitation to access audio and videos or complement elements of the RCN channel on television. RCN is the only channel that demonstrates commitment to advertorials on the web.

The platform's convergence is evident on the webpage of the radio station, since there is a section dedicated to further events information, photography, videos and other material found online and on social media (91\% own material, 1\% other stations, $8 \%$ social media). Reporters of the radio station contextualize these elements, which are part of the material that reporters also prepare on the air. The footer provides important information regarding the media's editorial and corporate social responsibility for the country. This communication tactic is transferred and adapted to the radio-app requirements.

Even though radio-apps of the radio stations keep the multimedia component (93\% textual, $3 \%$ audio, 3\% audiovisual and 1\% photography), the association with social media and the convergence with the on-air product, they differ from the other radio stations subject to this study. They focus their actions on enhancing the positioning strategy of the web-radio and the exclusive radio station online-RCN World. The station is committed to a new type and way to manage radio stations, where a musical segmentation is the banner to catch young's people attention. It is a multichannel view that seeks to face the connecting crisis with listeners on the dial.

On social media (4292 tweets, 2181 posts, 152 images and 88 videos were analyzed for RCN and 3881 tweets, 2303 posts, 142 images and 25 videos for La FM), the convergence between the antenna and the digital routines is confirmed (graph 6). The Radio Cadena Nacional, in its digital strategy, focuses its actions on communication platforms on disseminating information and topics developed on the air (91\%), leaving aside the interaction with followers (share publications of other users- $2 \%$, surveys and inquiries-6\%) and ignoring podcasts (1\%).

A qualitative analysis of radio station messages in the communication platforms denotes a digital strategy focused on strengthening the informative skills of the radio means, promoting web content access points of radio stations and revitalizing the trademark. The informative text of a social network is complemented by links to the website (95\%). At the same time, the names of the radio stations are included in the hashtags of the day (70\%). This tactic boosts the on-air work with messages that inform listeners what is happening during transmission (24\%), and it is complemented by the following multimedia tools: audio (1\%), video from other media (12\%), text and photography $(49 \%)$ and its own multimedia content $(14 \%)$, which achieves $73 \%$ reproduction.

The performance of digital stocks ( $\mathrm{RCN}$ is $15 \%$ Twitter, $76 \%$ Facebook, $4 \%$ Instagram and $90 \%$ YouTube, and FM is 32\%, 36\%, 19\% and $81 \%$, for each one) proves a degree of commitment from followers through the messages delivered by these two radio stations, which is similar to the commitment promoted by their competitors. Users respond to the dynamics of a business model focused on productive routines that aim at placing channel content as a reference for radio and which restores audience identification with the branch and its presence in the informative agenda of the country. It is a communicative proposal that merges the scenarios but also generates sound channels of exclusive proposals for the digital ecosystem.

\section{Conclusions}

The radio industry became the interpreter of society and the knowledge sharer in the digital environment. This industry assumes the role of a trans-media agent, an active 
narrator, a 'prosumer' (producer and consumer of content) and a mobilizing agent of communication spaces and cyberspace culture knowledge. It is an analogic-digital fusion able to understand computing programming, graphic design, telematics, photography, audio and video production, construction and management of websites, as well as the conception of strategies suitable for social media.

Radio establishes a harmonic synchronous communication system and on-air digital ecosystem bifurcation where micro-networks of activities are constituted. Radio also establishes a multimedia environment that conjugates the informative agenda of the station with users' interests. The radio industry suggests and experiments with new ways to inform and communicate.

The core business of the radio industry is still focused on sound and on-air entertainment. However, agents highlight the importance of incorporating radio into digital ecosystem dynamics. It is a new way to conceive the product and develop its narrative. Beyond innovation in content, new ways of acting are highlighted, and the radio means respond to production and audiovisual patterns that boost mobile devices in the market as follows: live (streaming), non-linear (podcast), guided through exploration of links, visualization of radio (cameras in studio-Facebook Live), notification and socialization of fragments in social media.

The business model integrates mediatized interrelation modalities to the productive routines of the radio industry. These elements are conceived from the conventional emission and are exploited so as to trend on social media and drive users to radio-web and radioapps by following the criteria of universal access and the concept of differential time in each place. Nowadays, theories and market schemes are addressed. Crossmedia dissemination facilitates reaching the public with the dynamics of trans-radio products displayed on the screens of portable devices. It is a change of culture that transforms the production and radial product consumption methods, ownership and empowerment of logical issues which are immersed and convergent in specific niches.

Radio stations indirectly drive their followers to a series of actions determined at a level of use and digital consumption. This situation arises as radio stations are supported in the brand leadership in the Colombian market, ranging from image and reputation to popularity. It is a scenario of implication and regulation of sensations. The convergence of on-air with web-radio and app-radio makes radio visible in different scenarios. This convergence radically reconfigures each and every one of the main processes of radio communication. Social autism of the radio industry reverses habits founded on the verbal monopoly. Radio understood the need to become part of an open and interactive context, an enculturation process, and has adapted to produce multimedia routines.

Social networks have become an extension of the radio ecosystem. It is an external element that reconfigures and modifies the communication model between the radio station and the listener-user, as well as the production of content and its dissemination. Radio included notifications into its digital tactical production routines. They are notifications that persuade listeners to listen to what is happening on the air, inform breaking news, provide continuity to news development and offer exclusive content. They are messages that support marketing aspects and drive consumption. Twitter, Facebook, Instagram and YouTube become sounding boards of whatever happens on-air, where radio enhances its proximity and interaction capacity with the audience.

Apps act as the evolution of transistors. They are the tool for radio to enter the portability of elements in cellphones and tablets. The radio industry synthesizes in apps the service menu of websites, which is an adaption to the characteristics imposed by ICT in search for continuity over time. Radio places itself in a multiform context; it is present in different scenarios (transistor, web, app, social media) and its marketing strategy combines with them. It is a mixture of exclusive contributions and content redundancy.

The complementarity of platforms takes place naturally and directly. The radio industry assimilated the presence of digital media and adapted to them in order to position itself as the backbone of content consumption by users. The digital ecosystem consolidates 
as the hub where radio and its audience meet, a logistic point of actions that bifurcates the business model, conditions the productive routines and converges with the on-air signal.

Funding: This research didn't receive funding from any particular organization.

Institutional Review Board Statement: Not applicable.

Informed Consent Statement: Not applicable.

Data Availability Statement: The data is not enabled in a public place. These are the data referenced in Table 2.

Conflicts of Interest: The author declares no conflict of interest.

\section{Notes}

1 There are three corporate groups in Colombia that own the country's main radio stations and are able to position their general-content stations as the audiences' favorites, according to the ECAR: Grupo Prisa, a media conglomerate from Spain and main shareholder of Cadena Radial Colombiana since 2004. Their staff includes Caracol Radio and W. Radio; Grupo Ardila Lulle, Colombian industrial businessman associated to communication media since 1976, as the owner of Radio Cadena Nacional that offers RCN Básica and La FM to the market; and Group Valorem, which came back to the radio industry in 2012 with Blu Radio, after a temporary step back in 2005, when they negotiated Cadena Radial Colombiana with the Prisa Spanish Conglomerate (Barrios-Rubio 2016).

2 Those people identified as Y generation, and were born in the 1980s and 1990s.

\section{References}

Aguaded, Juan Ignacio, and Luís Miguel Romero-Rodríguez. 2015. Mediamorfosis y desinformación en la infoesfera: Alfabetización mediática, digital e informacional ante los cambios de hábitos de consumo informativo. [Mediamorphosis and disinformation in the infosphere: Media, digital and information literacy in the face of changes in information consumption habits]. Education in the Knowledge Society 6: 44-57. [CrossRef]

Appel, Gil, Lauren Grewal, Rhonda Hadi, and Adrew Stephen. 2020. The future of social media in marketing. Journal of the Academy of Marketing Science 48: 79-95. [CrossRef]

Asnira-Zolkeplia, Izzal, and Yusniza Kamarulzamanb. 2015. Social media adoption: The role of media needs and innovation characteristics. Computers in Human Behavior 43: 189-209. [CrossRef]

Asociación Colombiana de Investigación de Medios. 2020. Estudio General de Medios en Cuarentena. [General Study of Quarantined Media]. Available online: http:/ / www.acimcolombia.com/boletines/presentamos-el-egm-cuarentena/ (accessed on 30 March 2021).

Barrios-Rubio, Andrés. 2011. De la onda a la Web: Paralelo entre la radio convencional y la radio virtual. [From the wave to the Web: Parallel between Conventional Radio and Virtual Radio]. Bogotá: Jorge Tadeo Lozano University.

Barrios-Rubio, Andrés. 2015. La radio colombiana frente al reto digital. [Colombian radio facing the digital challenge]. Comunicación y Medios 31: 113-31. [CrossRef]

Barrios-Rubio, Andrés. 2016. La radio generalista colombiana ante el desafío digital: Un modelo en transición. [Colombian Generalist Radio in the Face of the Digital Challenge: A Model in Transition]. Unpublished Doctoral thesis, Universitat Autònoma de Barcelona, Barcelona, Spain.

Barrios-Rubio, Andrés. 2020. R@dio en la sonoesfera digital. [R@dio in the digital sonosphere]. Bogotá: Aplha Editorial.

Barrios-Rubio, Andrés, and Maria Gutiérrez-García. 2016. Migration of the Colombian radio strategy: From sound to social screens. Revista Latina de Comunicación Social 71: 1.243-1.260. [CrossRef]

Barrios-Rubio, Andrés, and Maria Gutiérrez-García. 2017. Reconfiguración de las dinámicas de la industria radiofónica colombiana en el ecosistema digital. [Reconfiguration of the dynamics of the Colombian radio industry in the digital ecosystem]. Cuadernos.info 41: 227-43. [CrossRef]

Barrios-Rubio, Pedrero-Esteban Andrés, and Luís Miguel. 2021. The Transformation of the Colombian Media Industry in the Smartphone Era. Journal of Creative Communications 16: 45-60. [CrossRef]

Boyd, Danah, and Nicole Ellison. 2008. Social Network Sites: Definition, History, and Scholarship. Journal of Computer-Mediated Communication 13: 210-30. [CrossRef]

Bull, Michael. 2010. IPod: Un mundo sonoro personalizado para sus consumidores. [IPod: A personalized sound world for your consumers]. Comunicar 34: 55-63. [CrossRef]

Cabrera, María Ángeles. 2016. La innovación: Concepto y taxomización. [Innovation: Concept and taxomization]. In: Sábada, Charo, García, José Alberto, and Martínez-Costa, María del Pilar. (Coords). In Innovación y desarrollo de los cibermedios en España. [Innovation and Development of Cybermedia in Spain]. España: Editora EUNSA, pp. 23-30.

Cardona Bedoya, Jenny Marcela, and Yadira Carolina Vaca González. 2019. Tendencias de la radio online como apoyo a la construcción de estrategias propias para el medio. [Trends in online radio to support the construction of own strategies for the medium]. Anagramas Rumbos y sentidos de la comunicación 17: 177-201. [CrossRef] 
Crovi, Delia, Florence Toussaint, and Aurora Tovar. 2006. Periodismo digital en México. [Digital journalism in Mexico]. México: National Autonomous University of Mexico.

Fernández, José Luís. 2018. Plataformas mediáticas: Elementos de análisis y diseño de nuevas experiencias. [Media Platforms: Elements of Analysis and Design of New Experiences]. Buenos Aires: Crujía.

Flaxman, Seth, Sharad Goel, and Justin Rao. 2016. Filter Bubbles, Echo Chambers, and Online News Consumption. Public Opinion Quarterly 80: 298-320. [CrossRef]

Franquet, Rosa, María Isabel Villa, and Ignacio Bergillos. 2013. Public Service Broadcasting's Participation in the Reconfiguration of Online News Content. Journal of Computer-Mediated Communication 18: 378-97. [CrossRef]

García Jiménez, Antonio, Victoria Tur-Viñes, and Yolanda Pastor Ruiz. 2018. Consumo mediático de adolescentes y jóvenes. Noticias, contenidos audiovisuales y medición de audiencias. [Media consumption of adolescents and young people. News, audiovisual content and audience measurement]. Icono 14: 16, 22-46. [CrossRef]

Gutiérrez-García, Maria, and Andrés Barrios-Rubio. 2019. Del offline a la r@dio: Las experiencias de la industria radiofónica española y colombiana. [From offline to r@dio: The experiences of the Spanish and Colombian radio industry]. Revista de Comunicación 18: 73-94. [CrossRef]

Gutiérrez-García, Maria, and Andrés Barrios-Rubio. 2021. Youth sound consumption practices, between big platforms and the radio ecosystem: The case of Colombia-Spain. Comunicación Y Sociedad, 1-24. [CrossRef]

Hernández-Sampieri, Roberto, Carlos Fernández-Collado, and Pilar Baptista-Lucio. 2010. Metodología de la Investigación, 5 ed. [Research Methodology, 5 ed.]. México: McGrawHill.

Jenkins, Henry. 2008. Convergence culture. La cultura de la convergencia de los medios de comunicación. [Convergence Culture. The Culture of Media Convergence]. Buenos Aires: Paidós.

Kantar Ibope Media. 2019. Consumo de medios en Colombia. [Media consumption in Colombia]. Available online: http://www. kantaribopemedia.com.co/ (accessed on 30 March 2021).

Larrondo, Ainara, Simón Peña-Fernández, and Irati Agirreazkuenaga. 2020. Transmedia Apps for the Young Audiences. Implications and Uses in the Context of Public Service Broadcasters. In Active Audiences. Empowering Citizens' Discourse in the Hybrid Media System. Edited by Simón Peña-Fernández, Meso Koldo and Ainara Larrondo. New York: Mc Graw Hill Interamericana S.L.

Lizondo, Norma Liliana. 2018. La comunicación con identidad. Regulaciones y un estudio de caso. Anuario Electrónico de Estudios en Comunicación Social. [Communication with identity. Regulations and a case study. Electronic Yearbook of Studies in Social Communication]. Disertaciones 11: 50-65. [CrossRef]

Marta-Lazo, Carmen, and Miguel Ángel Ortiz. 2016. La información en radio. Contexto, géneros, formatos y realización. [Information on Radio. Context, Genres, Formats and Production]. Madrid: Editorial Fragua.

Martí, Josep María, María del Pilar Martínez-Costa, and Elisa Escobedo. 2019. El horizonte de las ondas digitales. [The horizon of digital waves]. In La transformación digital de la radio. Diez claves para su comprensión académica y profesional. [The Digital Transformation of Radio. Ten Keys to Your Academic and Professional Understanding]. Edited by Luís Miguel Pedrero-Esteban and José María García-Lastra. Valencia: Tirant Lo Blanch, pp. 267-90.

Martínez-Costa, María del Pilar. 2015. Radio y nuevas narrativas: De la crossradio a la transradio. [Radio and new narratives: From crossradio to transradio]. In Radio, Sound and Internet, Proceedings of Net Station International Conference. Edited by Madalena Oliveira and Fabio Ribeiro. Brasil: Centro de Estudos de Comunicação e Sociedade (CECS), Universidade do Minho, pp. 168-87.

Martínez-Costa, María del Pilar, and José María Legorburu Hortelano. 2020. Audio digital e interfaces de voz: Una nueva era para la sonosfera. [Digital audio and voice interfaces: A new era for the sonosphere]. In Cartografía de la comunicación postdigital: Medios y audiencias en la Sociedad de la COVID-19. [Postdigital Communication Mapping: Media and Audiences in the COVID-19 Society]. Edited by Luís Miguel Pedrero-Esteban and Ana Pérez-Escoda. Toronto: Thomson Reuters, pp. 303-29.

Martínez-Costa, María del Pilar, Javier Serrano-Puche, Idoia Portilla, and Cristina Sánchez-Blanco. 2019. Young adults' interaction with online news and advertising. Comunicar 59: 19-28. [CrossRef]

Mayoral, Javier, and Concha Edo. 2014. Tipología de vídeos en el periodismo digital español: Análisis cualitativo de cinco cibermedios. [Typology of videos in Spanish digital journalism: Qualitative analysis of five cybermedia]. Doxa Comunicación 19: 21-56. [CrossRef]

McHugh, Siobhan. 2016. How podcasting is changing the audio storytelling genre. The Radio Journal: International Studies in Broadcast and Audio Media 14: 65-82. [CrossRef]

McMullan, John. 2020. A new understanding of 'New Media': Online platforms as digital mediums. Convergence 26: $287-301$. [CrossRef]

Monclús, Belén, Maria Gutiérrez, and Xavier Ribes. 2015. Las apps radiofónicas en los dispositivos móviles en España: Del discurso estratégico de los operadores a su acción. [Radio apps on mobile devices in Spain: From the strategic discourse of operators to their action]. Comunicação, Cultura e Mídias Sociais. Anais do XIV Congresso Ibero-Americano de Comunicação IBERCOM 2015. Available online: http:/ / www.assibercom.org/download/Ibercom_2015_Anais_DTI-2.pdf (accessed on 30 March 2021).

Nogueira, Ana Gabriela, and Túñez-López Miguel. 2019. Multidimensional and Multidirectional Journalistic Narrative: From Tumbled Pyramid to Circular Communication. In Information Technology and Systems. Edited by Álvaro Rocha, Carlos Ferrás and Paredes Manolo. ICITS 2019. Advances in Intelligent Systems and Computing. Cham: Springer, Volume 918. [CrossRef]

Orihuela, José Luis. 2015. Los medios después de Internet. [The media after the Internet]. Barcelona: Editorial UOC. 
Ortega, Félix, and Claudia Galhardi. 2013. Propuesta Metodológica para el análisis de contenido de la parrilla de Televisión en Brasil: Análisis de un caso práctico en los estados de São Paulo, Rio Grande do Sul, Estado da Bahía. [Methodological Proposal for the content analysis of the Television grid in Brazil: Analysis of a practical case in the states of São Paulo, Rio Grande do Sul, State of Bahia]. In Ortega, Félix, and Claudia Galhardi. Actas $2^{\circ}$ Congreso Nacional sobre Metodología de la Investigación en Comunicación: Investigar la Comunicación hoy. Revisión de politicas científicas y aportaciones metodológicas, Proceedings of the 2nd National Congress on Communication Research Methodology: Investigating Communication Today. Review of Scientific Policies and Methodological Contributions. Available online: http:/ / uvadoc.uva.es/handle/10324/3038 (accessed on 30 March 2021).

Pedrero-Esteban, Luís Miguel, and Susuna Herrera-Damas. 2017. La notificación push como estrategia informativa de la radio en el entorno digital. [Push notification as an informational strategy for radio in the digital environment]. El Profesional de la Información 26. [CrossRef]

Pedrero-Esteban, Luís Miguel, Andrés Barrios-Rubio, and Virginia Medina-Ávila. 2019. Teenagers, smartphones and digital audio consumption in the age of Spotify. Comunicar 60: 103-12. [CrossRef]

Pérez Tornero, José Manuel, and Luis Miguel Pedrero Esteban. 2020. Las coordenadas digitales del ecosistema comunicativo. [The digital coordinates of the communication ecosystem]. In Cartografía de la comunicación postdigital: Medios y audiencias en la Sociedad de la COVID-19. [Postdigital Communication Mapping: Media and Audiences in the COVID-19 Society]. Edited by Pedrero-Esteban Luís Miguel and Pérez-Escoda Ana. Toronto: Thomson Reuters, pp. 37-56.

Pires, Fernanda, María José Masanet, and Carlos Scolari. 2019. What are teens doing with YouTube? Practices, uses and metaphors of the most popular audio-visual platform. Information, Communication E Society. [CrossRef]

Rajendran, Lavanya, and Preethi Thesinghraja. 2014. The Impact of New Media on Traditional Media. Middle-East Journal of Scientific Research 22: 609-16. [CrossRef]

Sádaba Chalezquer, Charo, and Ana Pérez-Escoda. 2020. La generación streaming y el nuevo paradigma de la comunicación digital. [The streaming generation and the new paradigm of digital communication]. In Cartografía de la comunicación postdigital: Medios y audiencias en la Sociedad de la COVID-19. [Postdigital Communication Mapping: Media and Audiences in the COVID-19 Society]. Edited by Luís Miguel Pedrero-Esteban and Ana Pérez-Escoda. Toronto: Thomson Reuters, pp. 97-114.

Said, Elias, Ana Serrano, Elvira García de Torres, Lyudmyla Yerezers'ka, and Mabel Calderín. 2013. La gestión de los Social Media en los medios informativos iberoamericanos. [The management of Social Media in the Ibero-American news media]. Comunicación $y$ Sociedad 26: 67-92.

Scolari, Carlos Alberto, and María-José Establés. 2020. Ecología mediática en tiempos de pandemia: Virus, comunicación e interfaces. [Media ecology in times of pandemic: Viruses, communication and interfaces]. In Cartografía de la comunicación postdigital: Medios y audiencias en la Sociedad de la COVID-19. [Postdigital Communication Mapping: Media and Audiences in the COVID-19 Society]. Edited by Luís Miguel Pedrero-Esteban and Ana Pérez-Escoda. Toronto: Thomson Reuters, pp. 57-72.

Serrano-Puche, Javier. 2017. Metaanálisis del consumo digital en el ecosistema mediático contemporáneo: Factores distintivos e implicaciones emocionales. [Meta-analysis of digital consumption in the contemporary media ecosystem: Distinctive factors and emotional implications]. Revista Mediterránea de Comunicación 8: 75-85. [CrossRef]

Silverman, David. 2000. Doing Qualitative Research: A Practical Handbook. London: Sage.

Smahel, David, Hana MacHackova, Giovanna Mascheroni, Lenka Dedkova, Elisabeth Staksrud, Kjartan Olafsson, Sonia Livingstone, and Uwe Hasebrink. 2020. EU Kids Online 2020: Survey Results from 19 Countries. London: London School of Economics and Political Science. [CrossRef]

Soengas, Xavier, and Miguel Ángel Ortiz Sobrino. 2018. The radio in Spain: The challenge of the digital coexistence facing the old structures and business models. In Trends in Radio Research: Diversity, Innovation and Policies. Edited by Ignacio Gallego, Manuel Fernández-Sande and Nieves Limón. Newcastle: Cambridge Scholars Publishing, pp. 327-40.

Taylor, Steven, Robert Bogdan, and Marjorie DeVault. 2015. Introduction to Qualitative Research Methods: A Guidebook and Resource, 4th ed. Hoboken: Wiley.

Tietaah, Gilbert, Margaret Amoakohene, and Damasus Tuurusong. 2019. Radio Redux: Audience Participation and the Reincarnation of Radio for Development in Africa. Journal of Developing Societies 35: 282-302. [CrossRef]

Tsujimoto, Masaharu, Yuya Kajikawa, Junichi Tomita, and Yoichi Matsumoto. 2018. A review of the ecosystem concept-Towards coherent ecosystem design. Technological Forecasting and Social Change 136: 49-58. [CrossRef]

Urchaga, José David. 2009. Análisis de Contenido. [Content Analysis]. In Diccionario Crítico de Ciencias Sociales. Vol. I. [Critical Dictionary of Social Sciences. Vol. I]. Edited by Román Reyes. Madrid: Universidad Complutense and PlazaValdís.

Velásquez, Andrea, Denis Renó, Ana María Beltrán, Juan Carlos Maldonado, and Carlos Ortiz León. 2018. De los mass media a los medios sociales: Reflexiones sobre la nueva ecología de los medios. [From the mass media to social media: Reflections on the new media ecology]. Revista Latina de Comunicación Social 73: 583-94. [CrossRef]

Wimmer, Roger, and Joseph Dominick. 1996. La investigación científica de los medios de comunicación. Una introducción a sus métodos. [Scientific Investigation of the Media. An Introduction to Their Methods]. Barcelona: Bosch. 